\title{
The Impact of Anthropogenic Intervention on the Walauwewaththa Wathurana Fresh Water Swamp Forest in Sri Lanka
}

Siriwardana S.H.S.M. * and Ven. Pinnawala Sangasumana

Department of Geography, University of Sri Jayawardenapura, Sri Lanka

\begin{abstract}
Swamp forests are considered as the late succession stage of a freshwater marsh ecosystem and it is the rarest wetland type in Sri Lanka, rich in biodiversity thus providing a number of ecosystem services. The Walauwewatta Wathurana has been identified as the most dynamic fresh water ecosystem in Sri Lanka. These rare forest ecosystems have been subjected to degradation over the past decades due to various reasons especially anthropogenic activities. A study was conducted to explore the magnitude of these impacts caused by anthropogenic activities. A household survey was conducted using a structured questioner and Participatory Rural Appraisals (PRA) and discussions were made to gather information from the people living close by the swamp. Data analysis based on both quantitative and qualitative techniques. It was revealed that, a large number of activities carried out in the surrounding area of the forest by the neighboring communities directly or indirectly were related to their livelihoods as well as for their daily household needs. The richness of the species and the abundance have decreased over the past two decades due to the unsustainable fishing activities, contamination of agro-chemicals as well as chemical effluents of rubber based industries, sand mining, bamboo and rattan industries located around the forest area. Therefore the Wathurana fresh water swamp forest has been subjected to degradation due to anthropogenic activities. Conservation strategies should be implemented to strengthen the sustainability of the ecosystem services provided by this freshwater swamp forest.
\end{abstract}

KEYWORDS: Anthropogenic Activities, Degradation, Ecosystem, Fresh Water Swamp Forest, Impact 


\section{INTRODUCTION}

Fresh water swamp forests can be defined as a major sub category among the global environmental systems presented by the international wet land classification. "These are the rare environmental systems based on pure and fresh water" (Wijesingha 1988). Fresh water swamp forests can also be defined as "the late succession stage of a freshwater marsh ecosystem" (Central Environmental Authority, 1994). These forests are formed as a result of monsoons and floods; when water is deposited on land or when low lands are submerged by water creating different layers and strata on the ground. This formation continues for a long period of time and as a result fresh water swamps are created. (Wijesingha 1988) These are considered as one of the most spectacular and significant environmental systems in the world.

These forests can be found in the northern latitude of 80 up to the southern latitude of 35 from the equator. But even in these areas fresh water swamps are distributed $1200 \mathrm{~m}$ above sea level around low tropical and sub-tropical areas. The trees surrounding these areas are connected to the soil. Trees in this are adapted to grow according to the soil conditions, floods and are able to grow freely in shallow water throughout the year. To define these kinds of areas, the word "waturana" is used in the Sri Lankan context. From this word, it can be directly defined that this natural creation is directly associated with water. There is a very important relationship among the fresh water forests, trees, animals and water. As a result of this special interconnection and the dynamic features, the fresh water swamps evidently become important to be studied.

These areas are rich in biodiversity as well as a very sensitive environmental system. They contribute to establish the environmental equilibrium of nature. Fresh water swamp forests not only become important to the environment, but it also serves many advantages for humans. The ability to hold a large capacity of water as the swamps are usually situated in low valley areas helps to store water and control its flow. This also helps to control and reduce the impact of floods. Also, fresh water swamp forests can function as a water purifier as it absorbs the poisonous elements in water which assures the clean conditions of drinking water around the area. But, many threats are levelled against these natural creations, owing to industrialization, increase of habitations, and mechanization which obstruct the flow of water. (Central Environmental Authority 1994)

The Wathurana fresh water swamp forest is one of the most spectacular creations of nature. In Sinhala, the word "Wathurana" means that it is an area where water gets collected from time to time. This forest is located in the town of Bulathsinhala, $25 \mathrm{~km}$ away from the Kalutara town in the Damparadugoda GN Division facing the enchanting beauty of the Kalu Ganga river. The forest is spread in an area of 62045 hectares. (1398/21, The Gazette, 2001. 04. $24)$. The forest area near in the lower valley of Kalu Ganga river is $100-150 \mathrm{~m}$ above the sea level. There are two main water resources in Wathurana: Kukulu Ela and Batapotha Ela. Wathurana can be found aligned to the left river bank of the Botapotha Ela which is a branch of the Kalu Ganga River. The two main types of soil in this area are: red and yellow podzolic and moist soil. Above these two layers of soil, a layer of carbonic material can be found. (Fernando 2013: 214). Since Wathurana forest is located in the lower wet zone, there is a unique and inherent climate. The monthly median temperature in the surrounding area is usually 27.3C. The annual rainfall is normally 4000$5000 \mathrm{~mm}$. (IUCN 2007). The main source of rainfall is the south-west monsoon. 
Even though Wathurana is a swamp area, it can be considered as a "swamp forest" because of the special formation of its trees and vegetation. The trees that can be identified in this area are also commonly seen in low country rainforests. In the Waturana swamp forest, two tree types that are point endemic can be identified (IUCN 2007). These are Horawal (Stemnoporus mooni), and Suwada (Mesua stylosa). The fauna that lives in this swamp forest are often species that face endangerment and often rare and indigenous. It must be specially noted that the swamp forest is located in a private land that belongs to the family of Wijesekara. According to the 1980 Environmental Act of number 47, the Wathurana swamp forest in the Walauwewatta fields was declared as an "environmental protection area" through the special gazette of 1398/21 in the year 2009. According to the gazette, the power to carry on tasks and to enact authority inside the swamp forest is given only to the Central Environmental Authority. (21 The Gazette , 2009. 04. 29)

Since the Wathurana swamp forest area is high in its biodiversity, there is more harm from human activities. This condition would bring out continuous damage and would evidently harm the existence of this environmental system. In 1980, the area of the swamp forest was estimated at nearly 11 hectares. But almost after 10 decades, the calculations show that the area consisted only of 6.0245 hectares as a result of the human invasions on the land which used to be occupied by the swamp forest. Under these circumstances, a study conducted on the impact of human involvement with regard to the Wathurana swamp forest is essential to identify and reduce the negative human involvement on this natural manifestation.

\section{METHODOLOGY}

The midpoint of the wathurana is located in between the $6^{\circ} 37^{\prime}-6^{\circ} 39^{\prime} \mathrm{NL}, 80^{\circ} 11^{\prime}-80^{\circ}$ 13'EL (IUCN, 2007. There are around 176 families living in the area of Damparadugoda where the study is being conducted. For the study $20 \%$ of the families in the area were selected. (Approximately $40 \quad$ Environmental Authority was consulted. families) .Data was collected using questionnaires, interviews, direct observations, Participatory Rural Appraisals (PRA) and Check list survey. The collected data was analyzed in both quantitative and qualitative methods. For documents of verification, the 2011 report issued by the Central Environmental Authority was consulted.

\section{RESULTS AND DISCUSSION}

\subsection{The Harmful effects on Forests due to Livelihoods.}

There are 630 people belonging to the 176 families living in the GN Division of Damparadugoda. When considering ownership of lands, $67.5 \%$ of land area is freehold lands, $15 \%$ occupied by land houses and $12.5 \%$ of the people live in state lands. The data pertaining to employment in the Damparadugoda area can be observed from the graph 3.1. When considering employment in this area, it can be observed that for each family at least one person is employed. For $32.5 \%$ of households, one individual, for $57.5 \%$, two members and for $10 \%$ of households, three members are engaged in employment.

The main vocation of most of the villagers is working as labors in plantation estates. They are most often engaged in the production of rubber, clearing of lands, plucking tea leaves, maintenance and cleaning of estates are commonly done. The main employment of about $47.5 \%$ of the 
villagers is based on the Wathurana swamp forest. Apart from that, about 27.5\% of the villagers are engaged in jobs such as masonry, carpentry and cleaning. About $17.5 \%$ are engaged in vocations connected to wood mills, garages, driving, and factories and mainly in industries that produce rubber related goods. The level of income of these people is in a low level and often it exceeds the monthly expenditure of each household.

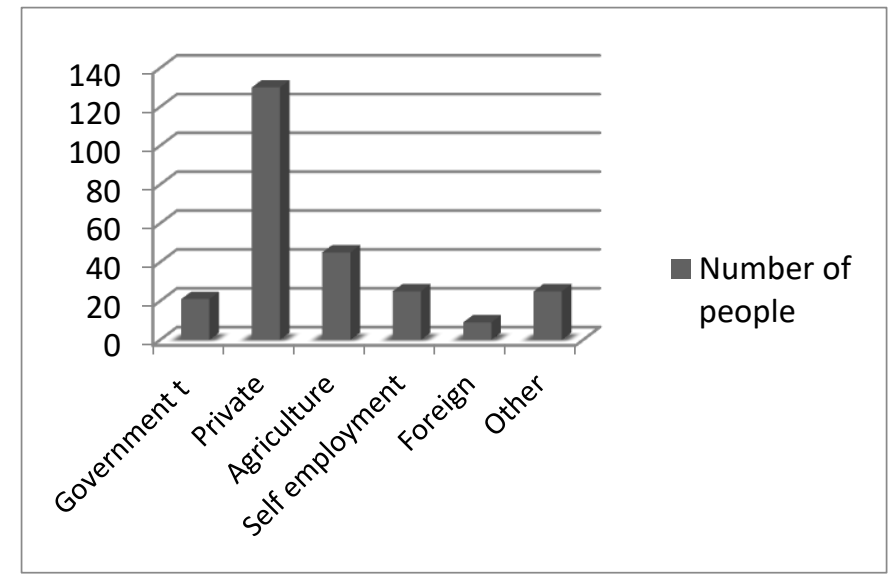

Graph: 3.1

Source: Resource profile, Bulathsinhala AGA Division

As a result of this situation, most of the people focus their attention on other jobs that would give theme additional income. Often, they turn to fishing, bamboo industry, cane industry, hunting, planting, sand mining, invention of sheet rubber and production of coal. The following pie chart (Graph no.3.2) shows the percentages of additional employment in the location in consideration for the study.

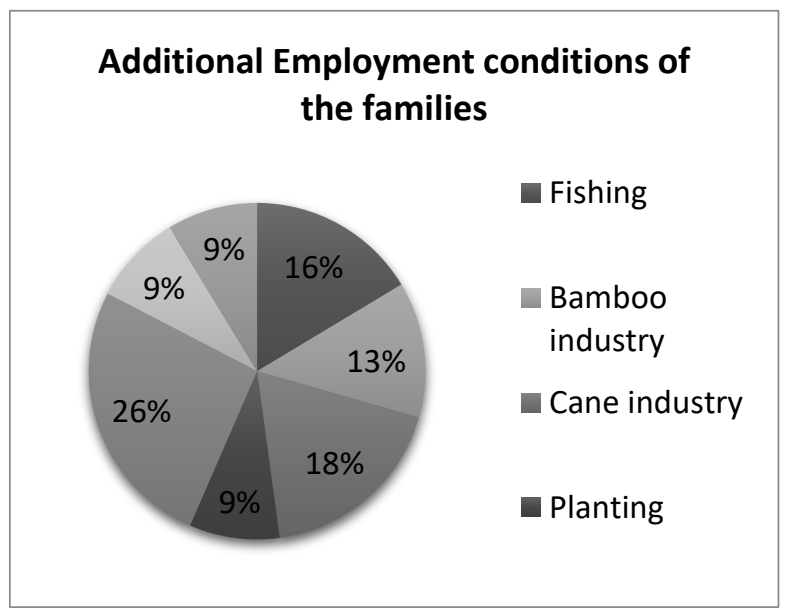

Graph: 3.2

Source: Resource profile, Bulathsinhala AGA Division, 2017 
According to the graph no1.2, the majority of the people consisting of $26.05 \%$ are engaged in soil lifting and $18.39 \%$ are engaged in the cane industry. $16.39 \%$ are engaged in fresh water fishing industry and 8.69\% each are engaged in rubber sheet production, planting and weeding and coal production. Most of these producers engaged in these different vocations and industries usually extract the needed resources from the nearby swamp forest.

\section{- Fresh water fishing industry}

Around the Wathurana area, people often use two major methods of fishing. They often fish using the most commonly used fishing rod or they use the method of placing fish traps. The most popular method is using the fish traps which are often done once the floods around Wathurana begin to recede. When the floods begin to retreat, the villagers would build barriers across the deepest pits in the streams using sand bags, pieces of wood and branches. (Photograph 3.1) The area which is abundant in tree roots is chosen by the fish as their habitats. They dig holes in these areas and create their own habitats. (Photograph 3.2) As a result the villagers surround these areas with wood and sand bags to catch fish.

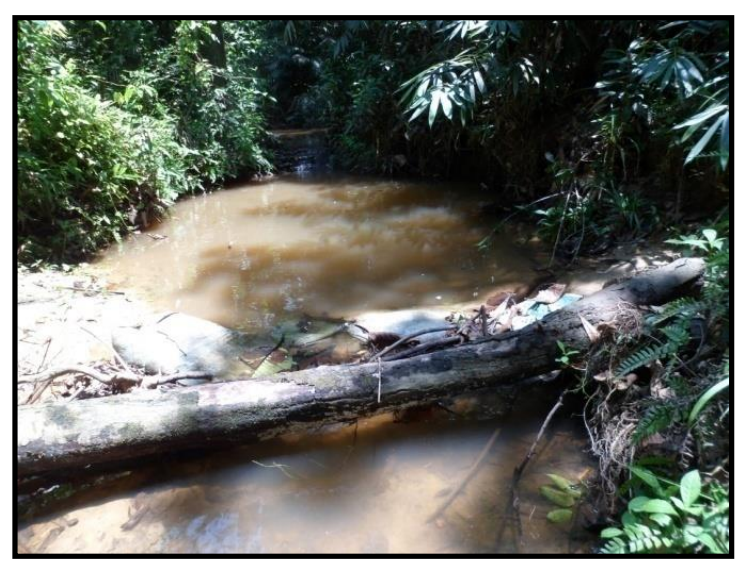

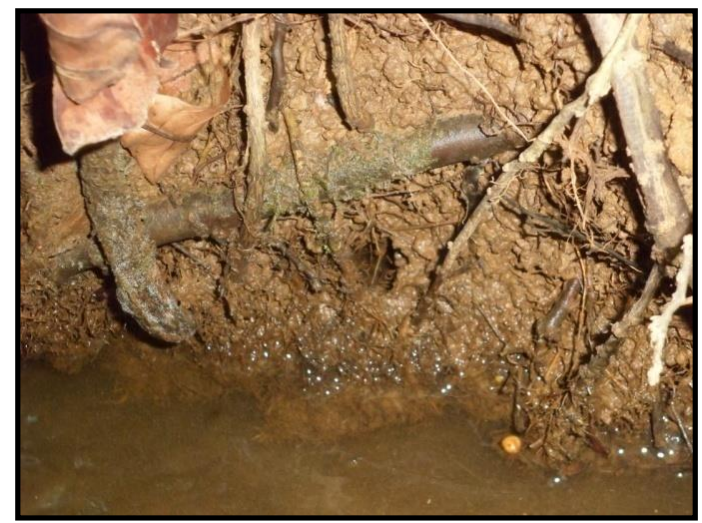

Create barriers and Nish nest

Photograph no. 3.1 \& 3.2

Source: Field data, 2017

The people cut off these nests built by the fishes using sharp equipment. After this step, they empty the water in the fishing trap. The remaining fish can be collected from the pit after the water has been drenched out of the pit. In this way, the villagers also destroy the holes where the fish lay their eggs. In the process of removing water out of the fishing traps, a lot of small fishes are killed and this causes a major decline in the population of fish in the swamp area.

\section{- The bamboo industry and the cane industry.}

About $13.06 \%$ of the villagers are engaged in the bamboo industry and the bamboo (Ochilandra stridula) that is necessary for this industry is extracted from the swamp area. Another major income generator of the Damparadugoda villagers is the cane industry. About $18.39 \%$ of the people are engaged in this industry.

\section{- Sheet rubber industry}

Around the Wathurana area, a lot of rubber plantations can be found and a lot of people are engaged in the creation of sheet rubber. They put acid to solidify the rubber and uses a rubber roller machine to remove the excess water. The rubber roller removes the 
excess water which is also infused with acidic substances and the water is disposed to the Kukulu Ela and Batapotha Ela streams. This causes harm for the fishes and the aquatic life that rests underneath these rivers.

\subsection{The harmful effects on the forests as a result of extraction of forest resources}

Most of the villagers depend on wood as a source of energy and they obtain wood from the surrounding forests. They use the soil around the area in building and construction. As the Wathurana area is rich in medicinal plants such as Hin Bovitiya, Iramusu, Samadara, Iratamadiya, Gonika and Muswanda. The villagers often extract these plants from the surrounding forest area. As a result indigenous plants with precious medicinal qualities have begun to disappear from the area.

\subsection{The harmful effects on the forest due to agriculture}

In the Wathurana area, 38 acres are already used for plantations and 39 acres are still not used for any form of plantations. The villagers engage in planting tea, rubber, coconut and vegetables. $60 \%$ of the villagers engage in agricultural vocations while they are engaged in other permanent vocations.

Agriculture is an inseparable part in their lives. $30 \%$ of the villagers engage in permanent agricultural vocations. Except the Eastern area known as "Honaka", all the other areas in Wathurana are flourished in agriculture and plantations of tea, rubber and coconut. The following graph no 3.1 clearly depicts the number of families that are engaged in agriculture in the area of Damparadugoda and the main plantations are tea, coconut and rubber.
Number of families and agricultural areas

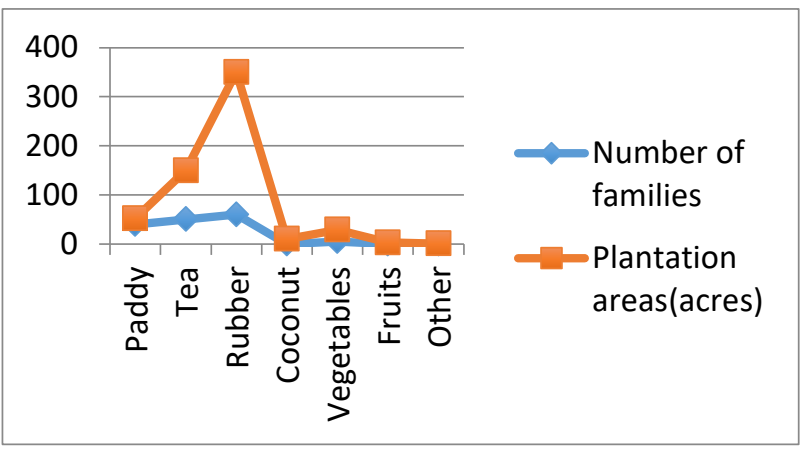

Graph: 3.

Source: Resource profile, Bulathsinhala AGA Division, 2017

The paddy famers in the area have acquainted themselves with different chemical usages. $26.67 \%$ of the villagers have been engaged in paddy cultivation for 1-5 years and $33.33 \%$ families have been engaged in the same cultivation for almost $5-20$ years. $60 \%$ of the population has been engaged in paddy cultivation for more than 20 years. Out of the areas where paddy is cultivated $53.3 \%$ is situated near the depths of valleys. To minimize the harmful effect of insects on the crops, the farmers have been using various methods from the ancient times. But now the situation has undergone a drastic change. Farmers have begun to use harmful pesticides and fertilizers consisting of urea, phosphate with high levels of chemicals and muriate of potash. Even though the famers in the past have used nature- friendly measures to safeguard their crops, the modern day cultivators have adopted these harmful fertilizers owing to the ease of usage. The ancient methods of eradicating pests are adopted by only $13 \%$ of farmers. Chemical fertilizers are used by $86.67 \%$ of farmers. For more than 10 years, farmers have been using these chemical fertilizers and pesticides for the sole purpose of obtaining better crops. It should also be noted that $93 \%$ of these farming lands are situated 
near water streams. These small water streams are directly or indirectly connected to the major waterways of Kukulu Ela and Batapotha Ela. The poisonous composition in the water ways and the addition of chemicals into the water and the neighboring fields has been taking place for a prolonged period of time. This has created many harmful threats and effects on the fishes and aquatic life. Apart from this, there is a large abundance of tea and rubber plantations in the surrounding area of the forest. In the area, agricultural activities are done in abundance including tea, rubber and paddy. About $58.3 \%$ of the land is owned by the land owners and they have continuously engaged in paddy cultivation for more than 20 years. These cultivation areas are situated above the altitude of Wathurana. As a result of this raised altitude, the chemicals and the fertilizers used in the cultivated lands easily washes into the swamps during the rainy season. As a result of this phenomenon, the aquatic and geographical systems are directly affected. This has hugely affected the reduction of aquatic life in the water sources in the Wathurana swamp forest.

Moreover, the people who live near the swamp forest dispose garbage along the periphery of the forest. Since the swamp forest consists of massively different bio diversity, many tourists, students and environmental enthusiasts visit to witness its beauty. Even though the swamp forest can be considered as an ideal place for experiments and observations, the bio diversity of the swamp forest can be easily harmed because of the sensitive nature of its vegetation and the excessive number of visits paid by the tourists. When a large crowd of people walk inside the forest at once, the small plants and vegetation grown inside the swamp forest are easily squashed and the forest cannot bear the weight of many footsteps. The horawal plant is easily affected by this phenomenon. Since houses and other construction sites can be seen up until the periphery of the swamp forest, Wathurana is directly exposed to the outer world. Continuous deforestation and the clearing of the swamp area for construction purposes directly affects the life span of the swamp forest as well as the fauna and flora that resides inside it. According to the graph 3.4 and 3.5 it is clear that there is a reduction of extracting forestry items for the usage of people. But it should be clearly noted that although there is a reduction of human intervention, still the harmful results done by humans to the swamp forests rest at a very high rate.

\section{The Changes that have taken place with}

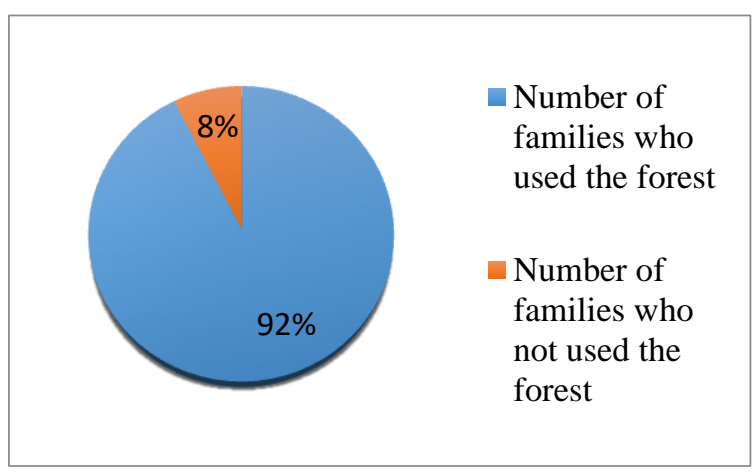

Graph no. 3.4

Source: Field data, 2017

Figure 3.1: The number of families that used Wathurana to extract forestry items 20 -25 years ago

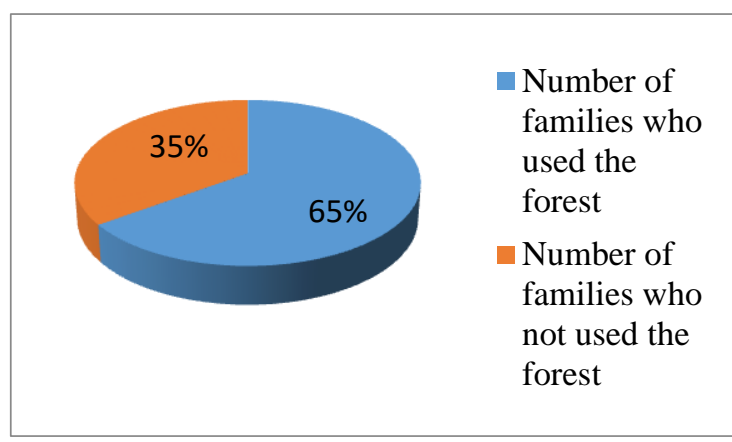

Graph no. 3.5

Source: Field data, 2017

Figure 3.1: The number of families that use Wathurana to extract forestry items at the moment 


\section{CONCLUSTION}

Wathurana is considered as an important natural manifestation where much endemic and rare aquatic speices can be discovered. It is home to different types of local flora and fauna. But due to many human actions the swamp has lost its allure. People have made pits in the river banks and on the depths of the rivers, As a result the fresh water fishes and aquatic life have begun to disappear. In the same way people have built artificial barriers around the rivers causing an extreme widening of the banks and excessive soil erosion. This action also contributes to the collapse of trees in the surrounding area. People excessively extract bamboo, cane, sand, wooden poles, clay and other natural material for their vocations and construction. Those who live closer to the Wathurana area usually engage in these activities and consider the swamp forest as an area essential for their daily survival. As a result of this excessive collection and extraction of natural items from the forest, a fast reduction of the fauna and flora can be seen. Another factor is the addition of chemicals and fertilizers released from the factories and industrial sites surrounding the area. The water resources are directly affected by the release of chemicals and create detrimental effects on the aquatic life as well. Since the swamp forest is located in the middle of many factories, the effect is inevitable and the release of chemicals to the swamp fields has been continuously happening for more than 15-20 years. The people living in the neighbouring area release their nondegradable garbage into the waterways creating more water pollution. Since the swamp forest is surrounded by rubber plantations, the rubber tree has become a threat to Wathurana. The rubber tree occupies a large area for its continuous growth and it blocks the growth of other plants in is surrounding area.

Even though this area of Wathurana fresh water swamp forest has been named by the
Central Environmental Authority as a environment protection area that must be secured, it seems that the people living in the area do not consider and value its importance. But it should be mentioned clearly that more than the older generation, the younger generation that resides near Wathurana swamp forest has developed an interest towards protecting and safeguarding this natural heritage. Their understanding about the importance is much greater than that of the older generation. Even though many studies have revealed that extraction of natural resources from it has caused a lot of damage to the forest, most villagers do not pay attention to the fact. They engage and continue in the task of extracting natural resources from the swamp forest without paying any attention to the damages that it might cause. This forest is a relatively small forest. When people continuously use the forest's resources for their own self gains, it can create a major impact on the loss of the beauty and the richness of the forest. The human actions will have a great impact on the existence of animals as well as the vegetation. Even though the Central Environmental Authority has named this area as a secured natural area, the government does not pay enough attention towards safeguarding these natural resources. Since the government has turned a blind eye towards safeguarding and educating people about the forest, the people have neglected the importance of the swamp forest. The need to protect, educate and spread awareness about the importance of the swamp forest has been crucial in the modern day. Steps must be taken to create a restricted area around the swamp, to educate the villagers, to take legal action and to develop more research and studies conducted on the swamp. 


\section{REFERENCES}

CEA, Walauwawathta waturana swamp forest, wetland site report, Colombo, Print shop, 1994:6-65

CEA, Walauwawathta waturana swamp forest, Summary of wetland site report, wetland conservation project, central, Colombo, environment authority, 1994:185189

CEA, An Environmental Profile of the Kaluthara District Central Environment Authority, Colombo, MEAP, 19921:78-79

IUCN, wetland directory, International union for conservation of Nature \& Natural Resources, Colombo, Country Office,2007: 225-227

WIJESINGHE.A.S, The unique swamp forest of Bulathsinhala is Still alive, Loris. 1988

Divitional secretariet office, Resource Profile, Bulathsinhala, 2017:34, 87-91

FERNANDO MANO., Kaluthara( exploration book), Thejani printers, Kaluthara, 2013:112 116 